\title{
Conjugative Plasmids and the Degradation of Arylsulfonates in Comamonas testosteroni
}

\author{
FRANK JUNKER ${ }^{1}$ AND ALASDAIR M. COOK ${ }^{1,2 *}$ \\ Microbiology Institute, Swiss Federal Institute of Technology, ETH-Zentrum, CH-8092 Zürich, \\ Switzerland, ${ }^{1}$ and Faculty of Biology, The University, D-78434 Konstanz, Germany ${ }^{2}$
}

\begin{abstract}
Comamonas testosteroni T-2 degrades $p$-toluenesulfonate (TSA) via $p$-sulfobenzoate (PSB) and protocatechuate and degrades toluenecarboxylate via terephthalate (TER) and protocatechuate. The appropriate genes are expressed in at least five regulatory units, some of which are also found in C. testosteroni PSB-4 (F. Junker, R. Kiewitz, and A. M. Cook, J. Bacteriol. 179:919-927, 1997). C. testosteroni T-2 was found to contain two plasmids, pTSA (85 kbp) and pT2T (50 kbp); a TSA ${ }^{-}$mutant (strain TER-1) contained only plasmid pT2T. $C$. testosteroni PSB-4, which does not degrade TSA, contained one plasmid, pPSB $(85 \mathrm{kbp})$. The type strain contained no plasmids. Conjugation experiments showed that plasmid pTSA (possibly in conjunction with pT2T) was conjugative, and the single copy of the TSA operon (tsaMBCD) with its putative regulator gene $(t s a R)$ in strain T-2 was found on plasmid pTSA, which also carried the PSB genes ( $p s b A C$ ) and presumably transport for both substrates. Plasmid pTSA was assigned to the IncP1ß group and was found to carry two copies of insertion element IS1071. Plasmid pPSB (of strain PSB-4), which could be maintained in strains with plasmid pTSA or pT2T, was also conjugative and was found to carry the PSB genes as well as to contain two copies of IS1071. In attempted conjugations with the type strain, no plasmid was recovered, but the PSB ${ }^{+}$ transconjugant carried two copies of IS1071 in the chromosome. We presume the PSB genes to be located in a composite transposon. The genes encoding the putative TER operon and degradation of protocatechuate, with the meta cleavage pathway, were attributed a chromosomal location in strains T-2 and PSB-4.
\end{abstract}

Arylsulfonates are widespread pollutants, some of which can easily enter drinking water $(7,15$; cf. 39$)$. Despite the multimillions of tons of sulfonates used each year $(6,13)$, they seldom accumulate in the environment (34), and some are obviously subject to biodegradation $(1,15)$. The arylsulfonate whose degradation is best understood is $p$-toluenesulfonate (TSA) in Comamonas testosteroni T-2, where part of the degradative pathway is common to the degradation of $p$-toluenecarboxylate (TCA) (Fig. 1). All of the enzymic proteins in this pathway have been separated, and usually purified $(13,29)$, and the structure of one operon (sequenced as $t s a M B C D$ ) with tsaR (encoding the putative regulator of $t s a M B C D$ ) in the degradative pathway of strain T-2 is known (13; cf. 41).

Enzymes for the degradation of xenobiotics can be plasmid or chromosomally encoded $(27,38)$ or both $(35)$. The genes encoding the degradation of at least one sulfonate, 2-aminobenzenesulfonate, are known to be located on a 117-kbp IncP9 plasmid (pSAH) in Alcaligenes sp. strain O-1 $(11,12)$; others are suspected to be found on plasmids $(5,9)$. Some catabolic plasmids display a high genetic flexibility due to transposons which are associated with catabolic genes. To date, only a few catabolic transposons are known in detail, and they have been reviewed recently (43).

Horizontal gene transfer (conjugation) is an effective mechanism for transfer of genetic elements among bacteria. Plasmids encoding antibiotic and heavy metal resistance are transferred easily among bacteria, being small and present in relatively high copy numbers (22). Conjugation of large catabolic plasmids under environmental conditions may be less frequent but nonetheless effective $(25,37)$. Pseudomonas in-

* Corresponding author. Mailing address: Faculty of Biology, The University, Universitätstr. 10, D-78434 Konstanz, Germany. Phone: (49) 753188 4247. Fax: (49) 75318829 66. E-mail: Alasdair.Cook @uni-konstanz.de. compatibility group P-1 (IncP1) plasmids are typical large catabolic plasmids which are prevalent in soil, manure slurries, and polluted environments (8). IncP1 plasmids, which have two subgroups, IncP1 $\alpha$ and IncP1 $\beta$ (44), are 50 to $100 \mathrm{kbp}$ in size, of which a $40-\mathrm{kbp}$ region is designated as the IncP1 backbone, encoding, e.g., maintenance, replication, incompatibility, and conjugation (40). IncP1 plasmids are thus capable of autonomous maintenance in the bacterial host and transfer to a wide range of gram-negative genera. The copy number per chromosome is four to six for Escherichia coli and two to three for Pseudomonas spp. (23).

The transport and degradation of toluenesulfonate in $C$. testosteroni T-2 are controlled in about five regulatory units (Fig. 1). Spontaneous mutation can lead to the loss of whole units, e.g., R1 (tsaMBCD and putative regulator tsaR) and R3 $[p s b A(C)]$, to give mutant TER-1 (Fig. 1) (14). The product from regulatory units $\mathrm{R} 1$ and $\mathrm{R} 3$, protocatechuate (PCA), is degraded via a meta pathway (Fig. 1), whose loss has not been observed. We have found identical enzymes ( $p$-sulfobenzoate [PSB] dioxygenase systems [PsbAC] and terephthalate [TER] dioxygenase systems [TerZ $\alpha \beta R]$ ) in two independently isolated strains of $C$. testosteroni, strains T-2 and PSB-4 (14). Strain PSB-4 does not contain R1 (14), and our interest lay in understanding the differences among these strains and the distribution of catabolic genes between plasmid and chromosome.

We now report that regulatory units $\mathrm{R} 1$ and $\mathrm{R} 3$ in $C$. testosteroni $\mathrm{T}-2$ are encoded on an $85-\mathrm{kbp}$ IncP1 $\beta$ plasmid, which is conjugative and which is missing in mutant TER-1. We believe that regulatory unit R3 is located in a transposon involving IS1071 insertion elements. C. testosteroni PSB-4 also encodes regulatory unit R3 on a conjugative plasmid, which does not belong to the IncP1 group but which presumably does involve a composite transposon incorporating IS1071 insertion elements. 


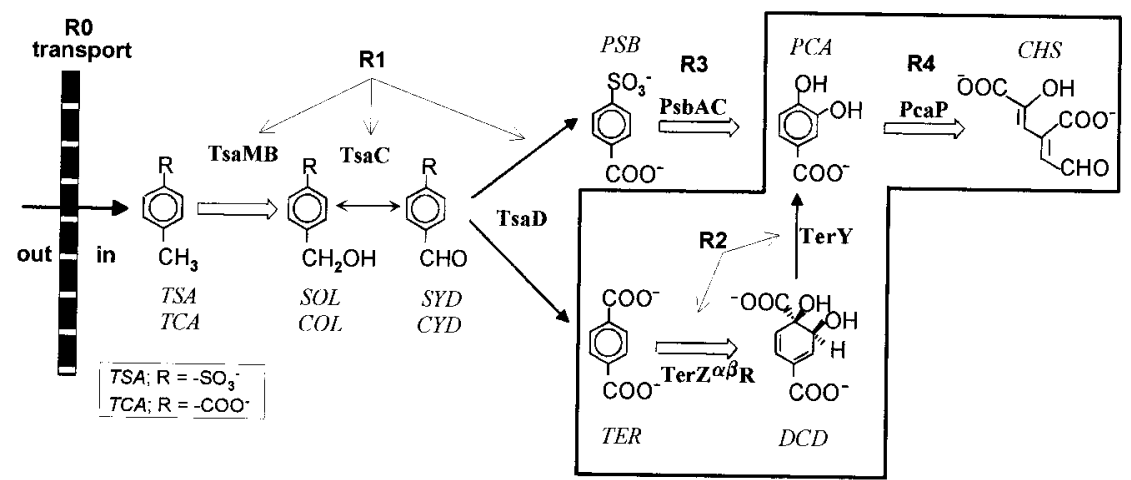

FIG. 1. Degradative pathways for TSA and TCA in C. testosteroni T-2, their regulation, and the portions of the pathway found in mutant TER-1 and in C. testosteroni PSB-4. TSA enters the cell via a physiologically characterized transport system, termed R0, which is coregulated with regulatory unit R1 but is distant from the known R1 operons tsaMBCD and tsaR $(13,18,29)$. TSA is oxygenated to $p$-sulfobenzyl alcohol (SOL) and further oxidized via $p$-sulfobenzaldehyde (SYD) to PSB, which is oxygenatively desulfonated to PCA. meta-cleavage to 4-carboxy-2-hydroxymuconate semialdehyde (CHS) follows. The appropriate catabolic enzymes are encoded in three regulatory groups, R1 (the TSA operon), R3 ( $p s b A C$ ), and R4 (at least $p c a P)(13,29)$. TCA presumably requires transport into the cell independent of TSA transport $(13,18)$, and TCA is oxygenated to carboxybenzyl alcohol $(\mathrm{COL})$ and further oxidized via carboxybenzaldehyde (CYD) to TER, which is oxygenated to the diene-diol (DCD) and decarboxylated to PCA. The appropriate catabolic enzymes are encoded in the TSA operon and regulatory unit R2 (the TER operon) (13, 17, 41). The enzymes are represented by abbreviations in boldface. A second organism under study is a mutant of strain T-2, named strain TER-1, which has lost regulatory units R1 and R3, but retains R2 and R4 (14). The third organism is C. testosteroni PSB-4, which contains no regulatory unit R1, but contains complete units R2, R3 and R4. The type strain of C. testosteroni, ATCC 11996, according to the literature (42), encodes the equivalent of regulatory unit R4. The enzymes shown in the irregular box are chromosomally encoded.

\section{MATERIALS AND METHODS}

Bacterial strains and plasmids. The organisms we used are shown in Table 1. C. testosteroni T-2 (DSM 6577) and C. testosteroni PSB-4 (DSM 11414) were isolated by Thurnheer et al. (36) and thoroughly identified (4). C. testosteroni TER-1 was isolated by A. Tien (14). Cells were grown at $30^{\circ} \mathrm{C}$ in mineral salts medium containing $6 \mathrm{mM}$ toluenesulfonate, sulfobenzoate, or TER as the sole source of carbon and energy, as described elsewhere $(16,28)$.

E. coli J53 harboring the plasmid IncP1 $\beta-\mathrm{R} 751$ or IncP1 $\alpha$-RP4 was kindly provided by K. Smalla and was grown on Luria-Bertani (LB) media at $37^{\circ} \mathrm{C}$ containing tetracycline (TC) $(30 \mu \mathrm{g} / \mathrm{ml})$ or trimethroprim $(30 \mu \mathrm{g} / \mathrm{ml})$.

PCR analysis. PCRs (Table 2) with total DNA or plasmid DNA were performed to assay for the presence of the genes encoding the TSA methyl-monooxygenase TsaMB (tsaMB) (13) or for the presence of the class II insertion sequence element IS1071 (20). The PCR product with primer pair tsaM-C and $t s a B-N$ was chosen to detect $t s a M B$ because it includes the $3^{\prime}$ end of oxygenase ts $a M$ and the $5^{\prime}$ start of reductase $t s a B$. The product with the primer pair tnp $A$ and $I R$, chosen to detect IS1071, includes the $3^{\prime}$ end of the transposase and the adjacent inverted repeat. The PCR mixture $(50 \mu \mathrm{l})$ contained $10 \mathrm{ng}$ of DNA, 200 $\mu \mathrm{M}$ (each) deoxynucleoside triphosphate (dNTP), 50 pmol of each primer, $5 \mu \mathrm{l}$ of dimethyl sulfoxide, and $0.25 \mathrm{U}$ of SuperTaq (Stehelin \& Cie, Basel, Switzerland) in the buffer supplied by the manufacturer. The PCR conditions used were $95^{\circ} \mathrm{C}$ for $5 \mathrm{~min}, 50^{\circ} \mathrm{C}$ for $30 \mathrm{~s}, 72^{\circ} \mathrm{C}$ for $40 \mathrm{~s}$, and $95^{\circ} \mathrm{C}$ for $45 \mathrm{~s}$. The last three steps were repeated 30 times.

PCRs for detection of IncP1 genes (Table 2) were carried out as described elsewhere (8). All primer pairs were deduced from genes belonging to the IncP1 plasmid backbone and were related to transfer (trf $A 2$ and korA) or replication (oriT).

Cloning and sequencing of the $\operatorname{trfA2}$ PCR product from plasmid pTSA. The 240-bp trfA2 PCR product from plasmid pTSA was separated on a $1.5 \%$ agarose gel and isolated by using the Geneclean Spin-Kit (BIO 101, La Jolla, Calif.). Before ligation, the $3^{\prime}$ ends of the PCR product were made blunt and the $5^{\prime}$ ends were phosphorylated. This was done in a $50-\mu \mathrm{l}$ reaction mixture containing 0.5 $\mu \mathrm{g}$ of PCR product, $12 \mathrm{U}$ of Klenow fragment, $40 \mathrm{U}$ of T4-polynucleotide kinase, $2.5 \mathrm{mM}$ (each) dNTP, $10 \mathrm{mM}$ dATP, and T4-polynucleotide kinase buffer which was then incubated for $1 \mathrm{~h}$ at $37^{\circ} \mathrm{C}$. The PCR product was ligated with pBluescript KSII vector which had been digested with SmaI. Nucleotide sequencing was performed by the modified dideoxy-chain termination method $(26,30)$ from double-stranded DNA templates by using PCR-based sequencing with digoxigenin-labeled primers and Taq polymerase (GATC-1500 DIG-Blotting Electrophoresis DNA Sequencer; GATC-Gesellschaft, Konstanz, Germany). Nucleic acid and amino acid sequences were analyzed by using the Genetics Computer Group program package (University of Wisconsin, Madison, Wis.). Restriction enzymes, Klenow fragment, T4-DNA ligase, polynucleotide kinase, and Taq polymerase were obtained from Fermentas, Vilnius, Lithuania.

Southern blot and dot blot hybridizations. Southern blotting, dot blotting, and radioactive labeling were performed by standard protocols (2). The primer probes (tsaM-C, $\operatorname{trf} A 2-1$, and $\operatorname{tnp} A$ ) (Table 2) were radioactively labeled. Digoxigenin-labeled PCR products of the IncP1 $\beta$ reference plasmid R751 for the genes oriT, $\operatorname{trf} A 2$, and korA were used as probes (blots of PCR products or total DNA dot blots) under stringent conditions appropriate for 75 to $100 \%$ nucleotide sequence similarity. In addition, probes of digoxigenin-labeled PCR products for $\operatorname{IncN}($ oriT $)$, IncQ(oriV), and $\operatorname{IncW}($ oriV $)$ plasmids were used under the same stringent conditions. The probes and primer systems used to identify the incompatibility group are not suitable to detect all plasmids belonging to the corresponding incompatibility group (8). All digoxigenin-labeled probes were kindly provided by K. Smalla (8).

Filter matings. Kanamycin (KM)-resistant recipient strains from C. testosteroni PSB-4, TER-1, and ATCC 11996 (type strain) were generated by screening for spontaneous mutants on plates containing KM $(50 \mu \mathrm{g} / \mathrm{ml})$. Cultures $(10 \mathrm{ml})$ of donor and recipient cells were grown overnight to an optical density at $600 \mathrm{~nm}$ of 0.6 , centrifuged, washed twice in $0.9 \% \mathrm{NaCl}$, resuspended in $150 \mu \mathrm{l}$ of $0.9 \%$ $\mathrm{NaCl}$, mixed together in $5 \mathrm{ml}$ of $10 \mathrm{mM} \mathrm{MgSO}_{4}$, and passed through a sterile filter (0.45- $\mu \mathrm{m}$-pore-size type HA; Millipore, St. Quentin, France). The filter was placed on an LB plate overnight (ca. $18 \mathrm{~h}$ ) at $30^{\circ} \mathrm{C}$. The cells were then washed off the filter with $5 \mathrm{ml}$ of $10 \mathrm{mM} \mathrm{MgSO}_{4}$, and $50 \mu \mathrm{l}$ of this suspension was plated on selective agar plates. Selection for the transconjugants of the donor-recipien pairs T2-PSB4, T2-TER1, and T2-TYPE was done on plates containing toluenesulfonate and KM (50 $\mu \mathrm{g} / \mathrm{ml})$ and that for PSB4-TER1 and PSB-4-ATCC 11996

TABLE 1. Bacteria used in this study

\begin{tabular}{|c|c|c|}
\hline Strain & Relevant characteristic(s) ${ }^{a}$ & Source or reference \\
\hline \multicolumn{3}{|l|}{ C. testosteroni } \\
\hline $\mathrm{T}-2$ & TSA, PSB, TER, PCA & DSM $6577^{c}$ \\
\hline PSB-4 & PSB, TER, PCA & DSM $11414^{c}$ \\
\hline $\mathrm{PSB}-4 \mathrm{~K}^{b}$ & PSB, TER, PCA, KM ${ }^{\mathrm{r}}$ & This study \\
\hline TER-1 & TER, PCA & 14 \\
\hline TER-1K $\mathrm{K}^{b}$ & TER, PCA, KM ${ }^{\mathrm{r}}$ & This study \\
\hline TYPE & PCA & DSM 50244 \\
\hline $\mathrm{TYPE}^{b}$ & PCA, $\mathrm{KM}^{\mathrm{r}}$ & This study \\
\hline \multicolumn{3}{|l|}{ E. coli } \\
\hline J53RP4 & $\begin{array}{l}\mathrm{Met}^{-}, \mathrm{Pro}^{-} \text {, plasmid } \\
\text { RP4 }\left(\mathrm{TC}^{\mathrm{r}}, \mathrm{KM}^{\mathrm{r}}, \mathrm{AP}^{\mathrm{r}}\right)\end{array}$ & K. Smalla \\
\hline J53R751 & Plasmid R751 (TP $)$ & K. Smalla \\
\hline $\begin{array}{l}\text { Pseudomonas putida } \\
\text { mt-2 }\end{array}$ & TOL-plasmid pWW0 & DSM 3931 \\
\hline
\end{tabular}

${ }^{a}$ Abbreviations indicate ability to degrade the respective compound. $\mathrm{KM}^{\mathrm{r}}$, $\mathrm{TC}^{\mathrm{r}}, \mathrm{AP}^{\mathrm{r}}$, and $\mathrm{TP}^{\mathrm{r}}$, resistance to kanamycin, tetracycline, ampicillin, and trimethoprim, respectively. $\mathrm{Met}^{-}$and $\mathrm{Pro}^{-}$indicate auxotrophy for these amino acids.

${ }^{b}$ These $\mathrm{KM}^{\mathrm{r}}$ organisms were used as recipients in conjugations, but to simplify nomenclature in the text we do not refer to the resistance marker there.

${ }^{c}$ See reference 36 . 
TABLE 2. Primer systems ${ }^{a}$

\begin{tabular}{|c|c|c|}
\hline Target & Primer pair $\left(5^{\prime}-3^{\prime}\right)$ & $\begin{array}{l}\text { Size of PCR } \\
\text { product (bp) }\end{array}$ \\
\hline tsaMB & $\begin{array}{l}t s a M-C, \text { AAAAATCTTGAGCCAGGT; } \\
t s a B-N, \text { TTGAGCTTTTCGTGAATC }\end{array}$ & 386 \\
\hline IS1071 & $\begin{array}{l}\text { tnp } A, \text { GTGGAATACCTCACAGATG; } \\
\text { IR, CGTTTTCAGTGCAATAAGTG }\end{array}$ & 338 \\
\hline \multirow[t]{3}{*}{ IncP1 } & $\begin{array}{l}\text { oriT-1, CAGCCTCGCAGAGCAGGAT; } \\
\text { oriT-2, CAGCCGGGCAGGATAGGTGAAGT }\end{array}$ & 110 \\
\hline & $\begin{array}{l}\operatorname{trf} A 2-1, \text { CGAAATTCRTRTGGGAGAAGTA; } \\
\operatorname{trf} A 2-2, \text { CGYTTGCAATGCACCAGGTC }\end{array}$ & 240 \\
\hline & $\begin{array}{l}\text { korA-1, ATGAAGAAACGGCTNACCGA; } \\
\text { kor } A-2 \text {, TTCCTGTTTYYTCTTGGCGTC }\end{array}$ & 294 \\
\hline
\end{tabular}

${ }^{a}$ Primers based on published sequence data were used to detect IncP1 plasmids, insertion element IS1071 and the genes $t s a M B$. ts $a M B$, toluenesulfonate methyl-monooxygenase (13); IS1071, class II insertion sequence element (20); IncP1, incompatibility group P-1 plasmid; oriT, origin of replication; trfA2, transacting replication function; korA, host-killing override factor (8).

was done on plates containing sulfobenzoate and KM $(50 \mu \mathrm{g} / \mathrm{ml})$. Controls for donor and recipient cells were plated separately on the same selective plates.

Conjugations were carried out with E. coli J53, harboring plasmid RP4, as donor, and strain T-2 or transconjugant T2-PSB4 as recipient, and transconju- gants were selected on $10 \mathrm{mM}$ succinate minimal medium plates containing TC $(50 \mu \mathrm{g} / \mathrm{ml})$.

PFGE. A contour-clamped homogeneous electric field system (model CHEFDRII; Bio-Rad Laboratories, Richmond, Calif.) was used to separate plasmid DNA on $0.9 \%$ agarose gels. Preparation of total DNA was done essentially as described previously (32). All experiments were done in TBE buffer (100 mM Tris- $\mathrm{HCl}, 100 \mathrm{mM}$ boric acid, $0.2 \mathrm{mM}$ EDTA [pH 8.3]) at $4^{\circ} \mathrm{C}$. The pulsed-field gel electrophoresis (PFGE) conditions used were $200 \mathrm{~V}$; running time, $22 \mathrm{~h}$; and pulse time, 20 to $120 \mathrm{~s}$. The chromosome of Saccharomyces cerevisiae YNN295 (Bio-Rad) was used as a linear DNA size marker. The plasmids pWW0, RP4, and R751 were used as supercoiled DNA standard markers.

Plasmid purification. Purifications of plasmids pTSA, pWW0, and R751 were performed according to the procedure described by Ish-Horowicz and Burke (10). The protocol was modified to include a phenol-chloroform extraction (8), and the isolated plasmid was further purified with a Geneclean Plasmid Spin-Kit (BIO 101).

Mercury and antibiotic resistance. Ampicillin (AM), KM, streptomycin, TC, trimethoprim (TP), or $\mathrm{Hg}$ resistance (at $10-$ and $50-\mu \mathrm{g} / \mathrm{ml}$ concentration) was tested in liquid medium for strains T-2, PSB-4, and TER-1.

Nucleotide sequence accession number. The accession number for the fragment of $\operatorname{trf} A 2$ we sequenced is GenBank U73743.

\section{RESULTS}

Plasmid pTSA of $C$. testosteroni T-2. PFGE showed that strain T-2 contains at least two megaplasmids (Fig. 2, lane 1). The larger plasmid was designated pTSA (from the TSA operon) (13), and the smaller plasmid was designated pT2T (see below). In contrast, mutant TER-1 (TSA ${ }^{-}, \mathrm{PSB}^{-}, \mathrm{PCA}^{+}$) contained only the smaller plasmid, pT2T (Fig. 2, lane 4; Table 3). The type strain (TYPE) of C. testosteroni $\left(\mathrm{TSA}^{-}, \mathrm{PSB}^{-}\right.$,

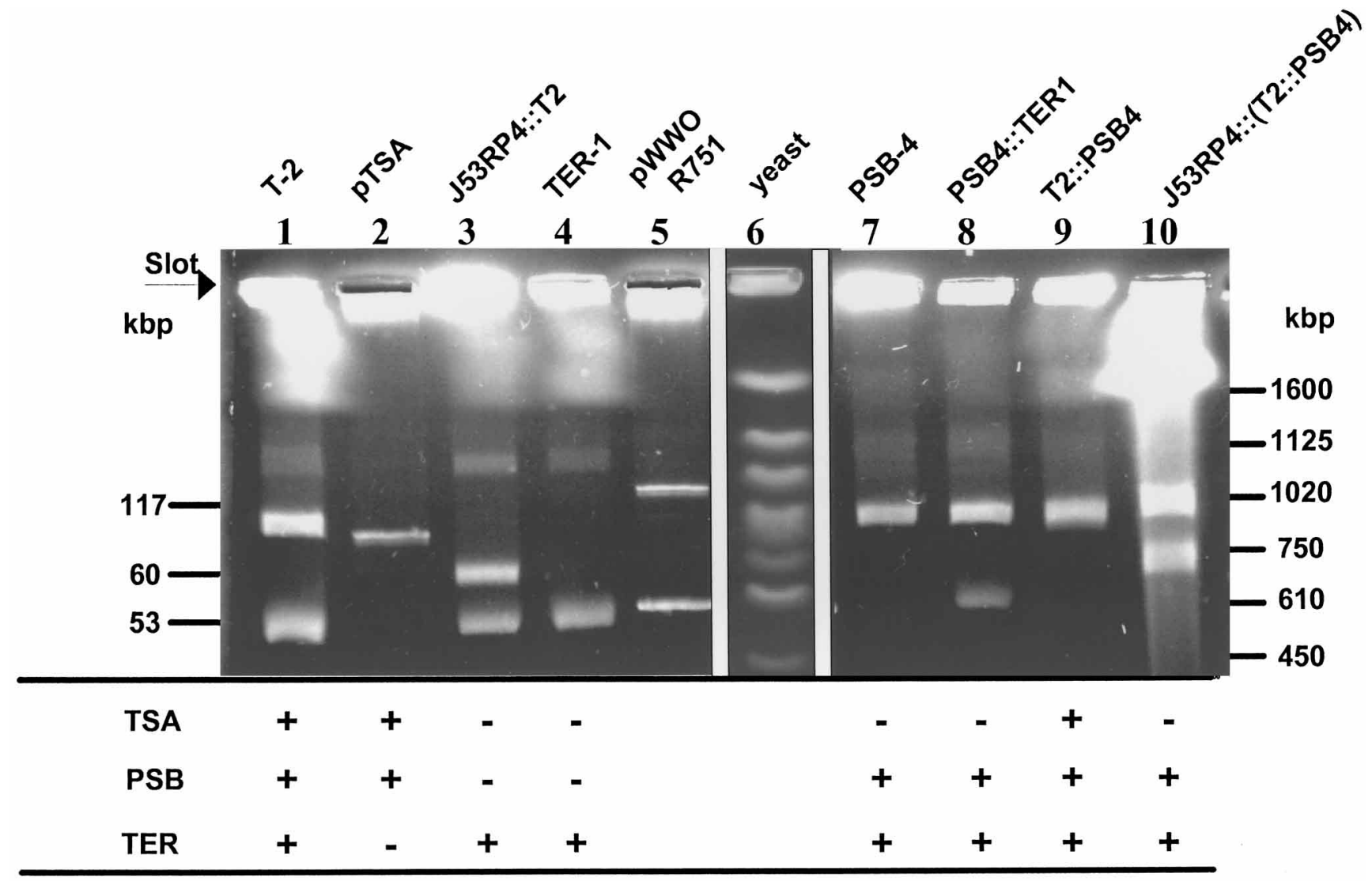

FIG. 2. PFGE of DNA from different strains of $C$. testosteroni and growth characteristics of these organisms. +, growth; - , no growth with substrate as sole source of carbon and energy. Lane 1, strain T-2; lane 2, plasmid pTSA; lane 3, transconjugant J53RP4-T2; lane 4, strain TER-1; lane 5, supercoiled plasmids pWW0 and R751; lane 6, yeast chromosomal DNA standard; lane 7, strain PSB-4; lane 8, transconjugant PSB4-TER1; lane 9, transconjugant T2-PSB4; lane 10, transconjugant J53RP4-(T2-PSB4). Sizes indicated at left for lanes 1 to 5 and at right for lanes 6 to 10. 
TABLE 3. Characteristics of C. testosteroni strains and transconjugants

\begin{tabular}{|c|c|c|c|c|c|c|c|c|c|c|}
\hline \multirow{2}{*}{ Strain or transconjugants } & \multicolumn{4}{|c|}{ Plasmid $^{a, b}$} & \multirow{2}{*}{$\begin{array}{c}\text { IS1071 } \\
\text { copy no. }\end{array}$} & \multicolumn{5}{|c|}{ Growth substrate $^{a}$} \\
\hline & pTSA & pPSB & $\mathrm{pT} 2 \mathrm{~T}$ & RP4 & & TSA & TCA & PSB & TER & PCA \\
\hline \multicolumn{11}{|l|}{ Strains } \\
\hline T-2 & + & - & + & & 3 & + & + & + & + & + \\
\hline PSB-4 & - & + & - & & 3 & - & - & + & + & + \\
\hline TER-1 & - & - & + & & 1 & - & - & - & + & + \\
\hline TYPE & - & - & - & & 0 & - & - & - & - & + \\
\hline \multicolumn{11}{|c|}{ Transconjugants (donor-recipient) } \\
\hline T2-PSB4 & + & + & - & - & $5^{c}$ & + & + & + & + & + \\
\hline T2-TER1 & + & - & + & - & $\mathrm{ND}^{d}$ & + & + & + & + & + \\
\hline PSB4-TER1 & - & + & + & - & ND & - & - & + & + & + \\
\hline J53RP4-T2 & - & - & + & + & 1 & - & - & - & + & + \\
\hline J53RP4-(T2-PSB4) & - & + & - & + & 3 & - & - & + & + & + \\
\hline T2-TYPE & + & - & + & - & 2 & + & - & + & - & + \\
\hline PSB4-TYPE & - & - & - & - & 2 & - & - & + & - & + \\
\hline
\end{tabular}

${ }^{a}+$, present (plasmid) or utilized (substrate); - , absent (plasmid) or not utilized (substrate).

${ }^{b}$ pTSA, IncP1 $\beta$ plasmid; RP4, IncP1 $\alpha$. Incompatibility group for pPSB or pT2T is unknown.

${ }^{c}$ Four bands, three strong and one weak, were seen on Southern blots, but one band derived from two plasmids, so five copies were present.

${ }^{d} \mathrm{ND}$, not determined.

$\mathrm{TER}^{-}, \mathrm{PCA}^{+}$) contained no detectable plasmid (Table 3). The ability to utilize toluenesulfonate and sulfobenzoate (but not TER) could be transferred via conjugation from donor strain T-2 to the type strain by transferring plasmid pTSA, whose presence (with pT2T) in T2-TYPE transconjugants was detected after PFGE (Table 3). Similarly, T2-TER1 transconjugants were $\mathrm{TSA}^{+}$and $\mathrm{PSB}^{+}$(and $\mathrm{TER}^{+}$) and contained both plasmids pTSA and pT2T (Table 3), and T2-PSB4 transconjugants were also $\mathrm{TSA}^{+}$but lacked plasmid pT2T (Table 3 ). Each of these transconjugants (T2-TYPE, T2-TER2, and T2PSB4) was shown to contain the genes $t s a M B$ by PCR (data not shown) and by Southern blot analysis (Fig. 3A and B, lanes 7 and 10; see also reference 14). These genes were first located on the pTSA plasmid in strain T-2 (Fig. 3A and B, lanes 1 and 3) but not in strain PSB-4, TER-1, or ATCC 11996 (Fig. 3A and $\mathrm{B}$, lanes 4 to 6). Association of the tsaMBCD genes (R1) with plasmid pTSA, which was shown to be conjugative (at least in the presence of plasmid pT2T), was thus confirmed. Plasmid pT2T is further detailed below.

The first attempt to obtain an organism which harbors only plasmid pTSA, transconjugant T2-TYPE, contained both plasmids (see above), although the selection was only for degradation of toluenesulfonate; no other attempts succeeded (see below). However, plasmid preparations from strain T-2, separated by PFGE, showed that plasmid pTSA was largely recovered, with only traces of plasmid pT2T and chromosomal DNA (Fig. 2, lane 2). Restriction enzyme analysis of PstI and BglIISalI digests of plasmid pTSA and Southern blot hybridization with a probe against the monooxygenase gene $t s a M$ gave signals of the sizes (1.8 kbp for Pst I [Fig. 3A and B, lane 1] and 4 $\mathrm{kbp}$ for $B g l \mathrm{II}-\mathrm{SalI}$ ) predicted by the restriction map and sequence of the TSA operon (13). Southern blot hybridizations of purified plasmid pTSA separated on PFGE gave signals with probes against $t s a M B$ (data not shown). The size of plasmid pTSA, $85 \pm 10 \mathrm{kbp}$, was first estimated by summing the sizes of restriction fragments obtained from a PstI (Fig. 3A, lane 1) or from a BglII-SalI digest. Supercoiled plasmid pTSA was located between plasmids pWW0 (117 kbp) and R751 (53 kbp), which confirmed the estimate of $85 \mathrm{kbp}$.

Catabolic genes are often associated with IncP1 $\beta$ plasmids $(3,21,24,31,33,43)$, so we probed by PCR for the presence of three conserved genes of IncP1 plasmids (Table 2) in total
DNA or in plasmid preparations from strains T-2, TER-1, and PSB-4. Products of the expected sizes (Table 2) were obtained from strain T-2 only (data not shown); no specific product was obtained from strains TER-1 and PSB-4. This presence of an IncP1 gene (e.g., $\operatorname{trf} A 2$ ) in strain T-2, but not in strain TER-1 or PSB-4, was confirmed by Southern blot analysis (Fig. 3, lanes 3 to 5), and the gene was located on plasmid pTSA (Fig. 3 , lane 1). We confirmed pTSA as being an IncP1 plasmid by mating strain T-2 (recipient) with E. coli J53RP4, which harbors the IncP1 $\alpha$ plasmid RP4. Selection for $C$. testosteroni and the IncP1 $\alpha$ plasmid RP4 gave the transconjugant J53RP4-T2 $\left(\mathrm{TSA}^{-}, \mathrm{PSB}^{-}, \mathrm{TER}^{+}\right)$, which had lost plasmid pTSA but contained plasmid RP4 instead, as well as plasmid pT2T (Fig. 2, lanes 1 and 3; Table 3). We were able to assign pTSA to IncP1 $\beta$ by first labeling the PCR products (oriT, $\operatorname{trf} A 2$, and kor $A$ ) of the IncP1 $\beta$ reference plasmid $\mathrm{R} 751$ with digoxigenin and then using these as probes in Southern blots of the PCR products and dot blots of total DNA from strain T-2 (data not shown) (8). Signals were obtained from the PCR products of strain T-2 and from the positive control, plasmid R751, but not for the IncP1 $\alpha$ control plasmid RP4.

The PCR product from the $\operatorname{trf} A 2$ primers with plasmid pTSA was cloned into pBluescript $\mathrm{KS}$ and sequenced. The deduced amino acids (from 240 nucleotides) were aligned with the $\operatorname{trf} A 2$ gene products from plasmids R751 and RK2 (Fig. 4). Identities of 95 and $87 \%$ between the PCR product and TrfA2 from plasmids R751 (IncP1 $\beta$ ) and RK2 (IncP1 $\alpha$ ), respectively, were found. The higher identity between the $\operatorname{trf} A 2$ gene of plasmid pTSA and R751, compared with that between plasmids pTSA and RK2, further supports the identification of pTSA as an IncP1 $\beta$ plasmid.

We conclude that the conjugative, $85-\mathrm{kbp}$ megaplasmid pTSA of strain T-2 belongs to the IncP1 $\beta$ group. Plasmid pTSA carries at least the operon tsaMBCD (R1) (Fig. 1), and the $\operatorname{psb} A(C)$ gene(s) of regulatory unit R3 and presumably transport R0.

Plasmid pT2T of strain T-2 and its mutant TER-1. The smaller megaplasmid, pT2T, of strains T-2 and TER-1 (Fig. 2, lanes 1 and 4), was found to have the same electrophoretic properties (by PFGE) as supercoiled IncP1 $\beta$ plasmid R751 and was estimated to be about $50 \mathrm{kbp}$ in length. Plasmid preparations of plasmid pT2T (from strain T-2 or TER-1) gave 


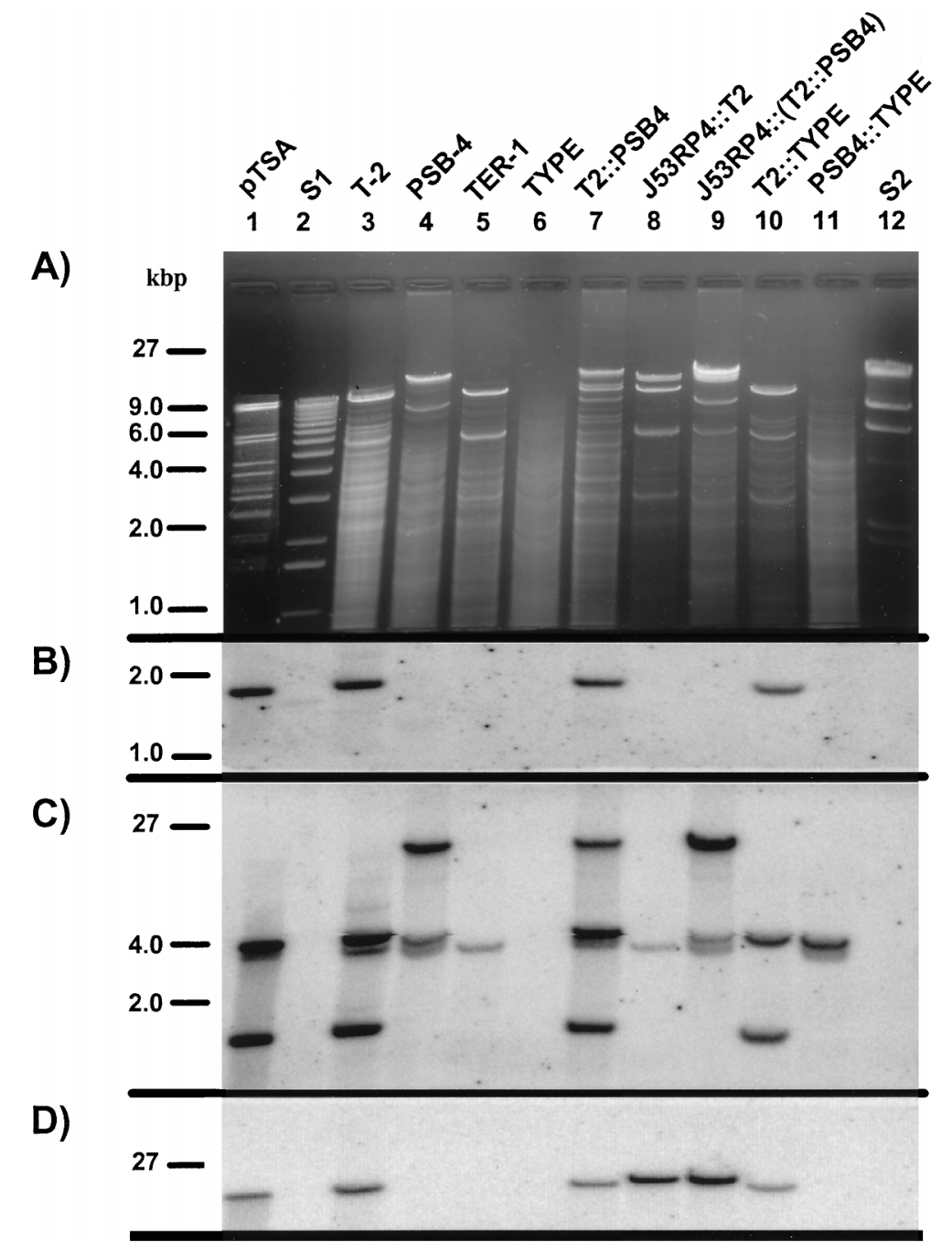

FIG. 3. PstI digests of plasmid pTSA and total DNA and Southern blot hybridizations with three different probes. (A) Southern blot with $0.75 \%$ agarose gel; (B) methyl-monooxygenase tsaM probe; (C) IS1071-tnpA probe; (D) IncP1-trfA2 probe. Lane 1, plasmid pTSA; lane 2, DNA ladder (kbp); lane 3, strain T-2; lane 4, strain PSB-4; lane 5, strain TER-1; lane 6, strain TYPE; lane 7, transconjugant T2-PSB4; lane 8, transconjugant J53RP4-T-2; lane 9, transconjugant J53RP4-(T2-PSB4); lane 10, transconjugant T2-TYPE; lane 11, transconjugant PSB4-TYPE; lane 12, $\lambda$-HindIII DNA marker.

low yields, and no catabolic function was found. However, plasmid pT2T was transferred in a mating experiment between strains T-2 (donor) and TYPE (Table 3) but not between strains T-2 (donor) and PSB-4 (Table 3 ). Its presence or absence did not lead to a change in the utilization of the substrates we studied, and it was not lost under nonselective conditions (growth on acetate or succinate). It does not belong to the IncP1 group, because it coexists with IncP1 plasmids pTSA (strain T-2 and transconjugant T2-TYPE) and RP4 (transconjugant J53RP4-T2) and no signals were obtained with specific IncP1 primers in PCR and Southern blots (Fig. 3, lane $5)$. Southern blots with IncW, IncN, and IncQ probes did not give a signal, but an affiliation with one of these groups cannot be excluded as the probes do not detect all members of the corresponding incompatibility group.

Plasmid pPSB of strain PSB-4. Only one plasmid was detected in C. testosteroni PSB-4, and it was termed pPSB (Fig. 2, lane 7). Mating experiments with strains PSB-4 (donor) and TER-1 yielded a PSB ${ }^{+}$transconjugant, PSB4-TER1 (Fig. 2, lane 8; Table 3), which contained plasmids pPSB and pT2T.
Plasmid pPSB is thus conjugative and carries the genes $p s b C$ for the oxygenation of sulfobenzoate (Fig. 1).

No PCR product was obtained with primers for conserved IncP1 genes (Table 2), so plasmid pPSB does not belong to the

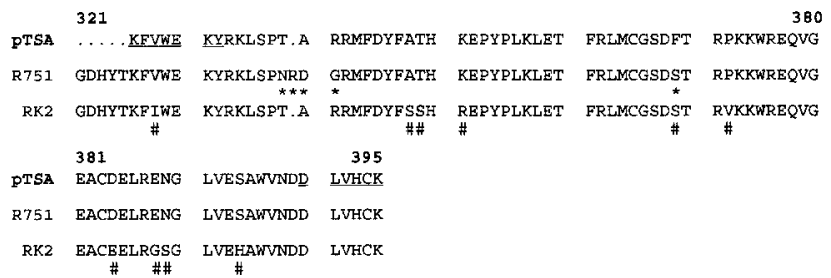

FIG. 4. Amino acid sequence alignment of the sequenced $\operatorname{tr} A 2$ PCR product ( $240 \mathrm{bp} ; \mathrm{AC}=\mathrm{U} 73743)$ from plasmid pTSA with TrfA2 proteins from plasmids $\mathrm{R} 751(\mathrm{AC}=\mathrm{U} 07618)$ and $\mathrm{RK} 2(\mathrm{AC}=\mathrm{U} 05774)$. The underlined amino acids were encoded by the $\operatorname{trf} A 2$ PCR primers. *, amino acid from TrfA 2 from plasmid R751 which is different from that of plasmid pTSA; \#, amino acid from TrfA2 from plasmid RK2 which is different from that of plasmid pTSA. The numbering is based on TrfA2 from plasmid R751. 
IncP1 group. This was confirmed in mating experiments with strains T-2 (donor) and PSB-4 which yielded a TSA ${ }^{+}-\mathrm{PSB}^{+}$ transconjugant (T2-PSB4) which was found to contain plasmids pPSB and pTSA, which comigrate, but not pT2T (Fig. 2, lane 9). Plasmid pTSA of strain T2-PSB4 could be cured with plasmid IncP1 $\alpha-\mathrm{RP} 4$ (Table 3 ), yielding an organism that was $\mathrm{TSA}^{-}$and $\mathrm{PSB}^{+}$and which contained plasmids pPSB and RP4 [J53RP4-(T2-PSB4)] (Fig. 2, lane 10). Plasmids pPSB and pT2T coexist in strain PSB4-TER1 so they belong to different incompatibility groups. As with plasmid pT2T, plasmid pPSB gave no signal in Southern blots with probes for IncW, IncN, and IncQ plasmids. Attempts to purify plasmid pPSB gave very poor yields. Comigration of plasmids pTSA and pPSB indicates that the latter is about $85 \mathrm{kbp}$.

Transconjugant PSB4-TYPE (Table 3) did not contain the plasmid but did gain the ability to grow on sulfobenzoate. The recombination of $p s b C$ with the chromosome and the possible involvement of the insertion element IS1071 is discussed below.

TER degradation. TerZ $\alpha \beta R$ was found to be identical in the independently isolated $C$. testosteroni strains PSB-4 and T-2 and in mutant TER-1 (14). The plasmid-free strain TYPE $\left(\mathrm{TER}^{-}, \mathrm{PCA}^{+}\right)$(Fig. 1) was used as a recipient in mating experiments. Transconjugant T2-TYPE $\left(\mathrm{TSA}^{+}, \mathrm{TCA}^{-}, \mathrm{PSB}^{+}\right.$, TER ${ }^{-}, \mathrm{PCA}^{+}$) contained plasmids pTSA and pT2T (Table 3 ), and transconjugant PSB4-TYPE ( $\left.\mathrm{PSB}^{+}, \mathrm{TER}^{-}, \mathrm{PCA}^{+}\right)$(Table 3 ) did not gain the ability to utilize TER (or toluenecarboxylate). We conclude that regulatory unit R2 (Fig. 1) is missing in these transconjugants. Plasmids pTSA, pPSB, and pT2T do not carry the genes ter $Z \alpha \beta R$ and terY (R2), which are apparently located on the chromosome.

Insertion element IS1071. Strain T-2 was found to contain insertion element IS1071 (43a). A Southern blot probe for the transposase of IS1071 (tnpA) (Table 2) revealed that two major copies of IS1071 were found in plasmid pTSA (4- and 1.7-kbp Pst I digests) (Fig. 3A and C, lane 1); the trace (below the 4-kbp band) was attributed to chromosomal contamination. In contrast, three copies of IS1071 were found in digests of total DNA from strain T-2; of these, two copies corresponded with those on plasmid pTSA, and the third copy, located at $3.8 \mathrm{kbp}$, was presumed to be chromosomal (Fig. $3 \mathrm{~A}$ and $\mathrm{C}$, lane 1). Correspondingly, only this latter copy was detected in strain TER-1 and transconjugant J53RP4-T2 (Fig. 3A and C, lanes 5 and 8), which lack plasmid pTSA, and no such copy was found in strain TYPE (seen here in transconjugant T2-TYPE [Fig. $3 \mathrm{~A}$ and $\mathrm{C}$, lane 10]). The intensity of the 3.8-kbp signal from T-2 total DNA was about 30 to $50 \%$ of that of the two signals of plasmid origin. On this basis, the copy number of plasmid pTSA lay in the range of two to three, which is typical for IncP1 plasmids (23). Plasmid pT2T cannot carry any copy of IS1071, because transconjugant T2-TYPE (Fig. 3C, lane 10), which harbors plasmids pT2T and pTSA, has only the two copies of IS1071, which were shown to originate in plasmid pTSA (Fig. 3C, lane 1).

Three copies of IS1071 were detected in digests of total DNA from strain PSB-4 (25-, 4-, and 3.8-kbp, PstI fragments) (Fig. 3A and $\mathrm{C}$, lane 4). The 4- and 3.8-kbp fragments were common to both strains T-2 and PSB-4. By analogy to the data from strain $\mathrm{T}-2$, we presume a chromosomal location for the IS1071 element in the 3.8-kbp PstI fragment and a plasmid (pPSB) location for the other copies. Correspondingly, transconjugant T2-PSB4, which harbors the plasmids pTSA and pPSB, showed three strong (plasmid-derived) signals and one weak (chromosomal) signal for the IS1071 probe. Of these three strong bands, the 4-kbp band is derived from two sources, plasmids pTSA and pPSB.
TABLE 4. Plasmids found in C. testosteroni T-2, PSB-4, and TER-1

\begin{tabular}{|c|c|c|c|c|c|c|}
\hline Plasmid & Strain(s) & Type & $\begin{array}{l}\text { Size } \\
(\mathrm{kbp})\end{array}$ & $\begin{array}{l}\text { Catabolic } \\
\text { genes }\end{array}$ & $\begin{array}{l}\text { Regula- } \\
\text { tory } \\
\text { unit(s) }\end{array}$ & $\begin{array}{c}\text { IS1071 } \\
\text { copy } \\
\text { no. }\end{array}$ \\
\hline pTSA & $\mathrm{T}-2$ & IncP1 $\beta$ & 85 & $\begin{array}{l}t s a M B C D(t s a R),{ }^{a} \\
\quad p s b A\end{array}$ & R1, R2 & 2 \\
\hline pPSB & PSB-4 & Unknown & 85 & $p s b A C$ & R2 & 2 \\
\hline pT2T & T-2, TER-1 & Unknown & 50 & $\mathrm{ND}^{b}$ & & Non \\
\hline
\end{tabular}

${ }^{a} t s a R$ encodes a putative transcriptional LysR-type regulator for the operon tsaMBCD.

${ }^{b} \mathrm{ND}$, not detected.

Transconjugant PSB4-TYPE grew with sulfobenzoate but did not contain a plasmid. Two copies of IS1071 were detected in Pst I digests (4 kbp and $3.8 \mathrm{kbp}$ ), but the $25-\mathrm{kbp}$ fragment was missing. The 4-kbp signal was stronger than the 3.8-kbp signal and may be identical with the 4-kbp signal from plasmids pTSA and pPSB. We cannot explain the weak, 3.8-kbp signal, which may resemble the 3.8-kbp chromosomal fragment of strains T-2, PSB-4 and TER-1, and which was not found in strain TYPE (see above), so given other nonspecific signals (see below), we cannot exclude the possibility that this 3.8-kbp Pst I signal is nonspecific.

Data and interpretations based on PstI digests were confirmed by independent BglII-SalI digests (data not shown). However, in addition to the signals just discussed, Southern blots of BglII-SalI digests showed an additional weak signal which is presumably nonspecific.

Strains T-2, PSB-4, and TER-1 were AM resistant. Streptomycin resistance occurred after a longer lag phase (2 to 3 days) but no other resistance (e.g., mercury) was found. Most $\mathrm{Co}$ mamonas strains are AM resistant (42), so it seems likely that this resistance is chromosomally encoded.

\section{DISCUSSION}

Whereas the type strain of $C$. testosteroni contains no detectable plasmids, the more recent isolates from the environment (strains T-2 and PSB-4) contain conjugative megaplasmids from at least three incompatibility groups (Table 4), and these plasmids can maintain themselves in different $C$. testosteroni hosts. We are as yet uncertain whether all three plasmids are conjugative: plasmid pPSB from strain PSB-4 could be transferred among strains of $C$. testosteroni, whereas transfer and maintenance of plasmid pTSA were always in the presence of plasmid pT2T (strain T-2 and transconjugant T2-TYPE) or pPSB (transconjugant T2-PSB4).

Plasmid pTSA, at $85 \mathrm{kbp}$, is sufficiently large to carry all the genes required for conjugation, which together with the replicatory functions, require some $40 \mathrm{kbp}$ (see Introduction). The catabolic genes $[t s a M B C D$ with regulator $t s a R$ and $p s b A(C)]$ (Fig. 1) and presumably those for a transport function for at least toluenesulfonate (13) can, thus, be easily accommodated.

IncP1 plasmids have an average GC content of $62 \%$ (23), which we have confirmed for one gene on plasmid pTSA (62.5\% for $\operatorname{trf} A 2$ PCR product) (Fig. 4). The GC content of the tsaMBCDR genes, $70 \%$, indicates a different origin of these genes. Chromosomal DNA of $C$. testosteroni also has an average GC content of $62 \%$ (42), which is valid for strain T-2 (4), so the origin of the $t s a M B C D R$ genes remains unclear. A GC content of $70 \%$ tends to indicate Pseudomonas-like organisms.

IS1071 is found on plasmid pUO1, in Moraxella sp. strain B, flanking a dehalogenase (dehH2) (43). Transposon Tn5271 (17 kbp) of Alcaligenes sp. strain BR60 is a composite transposon 
flanked by IS1071 (20). This class I element contains three genes (cbaABC, which encode 3-chlorobenzoate-3,4 dioxygenase oxygenase, the corresponding reductase, and a dehydrogenase, respectively) and is located on the $88-\mathrm{kbp}$ IncP1 $\beta$ plasmid, pBRC60. Tn5271 can integrate into the chromosome when conjugated with the incompatible plasmid pGS65 or R68 and can be remobilized by plasmid pBRC40 or R68, respectively. It has also been reported that Tn5271 transposes into $C$. testosteroni ATCC 11996 (43). However, IS1071 (3.2 kbp in total with 110-bp inverted repeats on either side) itself belongs to the class II transposons, and in spite of a missing resolvase, it has been shown to be a functional transposon (43). CbaAB is a class IA multicomponent mononuclear iron oxygenase system, whose oxygenase component has $45 \%$ identity with the $\mathrm{N}$-terminal region of PsbA (class IA) over the available 35amino-acid protein microsequence $(19,21)$, which could indicate a higher than average similarity of the two enzymes in the class IA.

Both $85-\mathrm{kbp}$ plasmids pTSA and pPSB contain two copies of insertion element IS1071, which suggests the presence of a composite transposon possibly analogous to Tn5271. We conclude that the transconjugant PSB4-TYPE $\left(\mathrm{PSB}^{+}\right)$is in part generated by a transposition event involving IS1071, so we presume that genes $p s b A C$ are included in the transposition element, and we are examining this element. Apart from possible similarities to Tn5271, the oxygenase component PsbA of dioxygenase PsbAC is identical in plasmid pTSA from strain T-2 and in plasmid pPSB from strain PSB-4 (14), whereas the reductase has been lost from, or inactivated in, strain T-2, where the regulation has also suffered alteration (29). We hope to establish what led to these changes.

The strains T-2 and PSB-4 have not only the plasmid-borne IS1071 sequences but also presumably a chromosomal copy of this insertion element. Wyndham et al. (43) suggested a mechanism whereby this could occur during generation of a composite transposon.

We find that the TER genes (R2) (Fig. 1) are chromosomally located, and we presume that the PCA genes (R4), with all meta cleavage pathway genes, are also chromosomal because the plasmid-free type strain utilizes PCA (Table 3). In contrast, the toluenesulfonate genes (R1) and the sulfobenzoate genes (R3) are located on a plasmid. So the degradation of both toluenecarboxylate via TER and that of toluenesulfonate via sulfobenzoate in strain T-2 are examples of complementation between chromosomally and plasmid-encoded catabolic pathways which differ in detail. Plasmid pTSA carries all genes (R1 and R3) necessary to degrade toluenesulfonate to PCA; thereafter, the chromosomal genes are required. Toluenecarboxylate, via TsaMBCD, is taken only to TER before the chromosomal genes (ter and pca) take over. A similar situation is found in the degradation of 2,4-dichlorophenoxyacetic acid (22). In this particular case chromosomally encoded maleylacetate reductase is required for further metabolism of the intermediate generated by the plasmid (IncP1 $\beta$ plasmid $\mathrm{pJP} 4$ )encoded enzymes. Neither TER, PCA, nor maleylacetate can be considered as xenobiotics, but the requirement for chromosomally located genes limits the host range of these catabolic plasmids. In contrast, the TOL plasmid codes for the degradation of, e.g., toluene to acetyl-coenzyme A, a central metabolite.

Previously, we discussed the possibility that strain PSB-4 developed from strain T-2 by loss or crypticity of the TSA operon (29). We reduced these possibilities to loss of the TSA operon in a later study when we showed that a major portion of the TSA operon was not present in strain PSB-4 (14). The present data show that loss of the TSA operon from plasmid
pTSA did not occur, because the putative residual plasmid, pPSB, is in a different incompatibility group from the plasmid, pTSA, which would have to suffer the deletion. These different incompatibility groups would allow comaintenance of plasmids pPSB and a putative precursor of pTSA, and the latter could have gained regulatory unit R3 by transposition. The complete pTSA could then enable a $\mathrm{TER}^{+}-\mathrm{PCA}^{+}$recipient strain to grow on both toluenesulfonate and toluenecarboxylate.

DNA rearrangements in plasmids and chromosomal insertions are well known in the literature. Top et al. (37) showed homologies and high diversities among 2,4-dichlorophenoxyacetic acid-degradative plasmids (related to pJP4) (3) isolated from soil; six out of seven were IncP1 plasmid derivatives, but no transposable element was found. The IncP1 $\beta$ plasmids pBRC60 and pSSD50 (33) exhibit a high genetic flexibility based on transposons. In contrast, the TSA and PSB genes of plasmid pTSA did not integrate into the chromosome when conjugated with IncP1 $\alpha$ plasmid RP4, whereas the PSB genes from plasmid pPSB recombined into the chromosome of the transconjugant without applying selective pressure to cure plasmid pPSB. Our finding that the degradation pathway of toluenesulfonate is clustered into three regulons (R0, R1, and R3) that can be found on different plasmids or on the chromosome supports the hypothesis that the evolution of degradative plasmids is based on the assembly of previously independent pathways mediated by flexible genetic elements, and more recent work has indicated the modular nature of these events (38).

Surprisingly, this would appear to be the first report of catabolic genes on a defined plasmid in C. testosteroni, despite the very large number of degradative abilities reported in this species and its widespread prevalence in the environment (42). These data confirm preliminary results indicated by Hooper (9) and suggest that the roles of, e.g., the broad-host-range IncP1 $\beta$ plasmids and transposable elements in the genetic flexibility of Comamonas spp. have been underestimated in the past.

\section{ACKNOWLEDGMENTS}

We are grateful to T. Leisinger, ETHZ, for his generosity with advice, space, and apparatus; to M. A. Kertesz, ETHZ, for discussions and advice; C. Wyndham, Carleton University, Ontario, Canada, for introducing us to IS1071 and for his advice; K. Smalla and E. Krögerrecklenfort, BBA-Braunschweig, for hosting F.J., for gene probes and for help with plasmid identification; A. Tien, EAWAG, for obtaining strain TER-1; S. Beil, GBF-Braunschweig, and J. Ruff, Konstanz, for discussions; and N. Ivos, ETHZ, for sequencing.

F.J. was supported by a grant (5001-035285) from the Priority Program Environment of the Swiss National Science Foundation.

\section{REFERENCES}

1. Altenbach, B. W. 1996. Ph.D. dissertation. Swiss Federal Institute of Technology, Zürich, Switzerland.

2. Ausubel, F. M., R. Brent, R. E. Kingston, D. D. Moore, J. G. Seidman, J. A Smith, and K. Struhl. 1994. Current protocols in molecular biology. Wiley, New York, N.Y.

3. Burlage, R. S., L. A. Bemis, A. C. Layton, G. S. Sayler, and F. Larimer. 1990. Comparative genetic organization of incompatibility group $\mathrm{P}$ degradative plasmids. J. Bacteriol. 172:6818-6825.

4. Busse, H.-J., T. El-Banna, H. Oyaizu, and G. Auling. 1992. Identification of xenobiotic-degrading isolates from the beta subclass of the Proteobacteria by a polyphasic approach including $16 \mathrm{~S}$ rRNA partial sequencing. Int. J. Syst. Bacteriol. 42:19-26.

5. Cain, R. B. 1981. Microbial degradation of surfactants and "builder" components, p. 323-370. In T. Leisinger, A. M. Cook, R. Hütter, and J. Nüesch (ed.), Microbial degradation of xenobiotics and recalcitrant compounds. Academic Press, London, United Kingdom.

6. de Almeida, J. L. G., M. Dufaux, Y. Ben Taarit, and C. Naccache. 1994 Linear alkylbenzene. J. Am. Oil Chem. Soc. 71:675-694.

7. Field, J. A., and E. M. Thurman. 1996. Glutathione conjugation and con- 
taminant transformation. Environ. Sci. Technol. 30:1413-1418.

8. Goetz, A., R. Pukall, E. Smit, E. Tietze, R. Prager, H. Tschaepe, J. D. van Elsas, and K. Smalla. 1996. Detection and characterization of broad-hostrange plasmids in environmental bacteria by PCR. Appl. Environ. Microbiol. 62:2621-2628.

9. Hooper, S. W. 1994. Biodegradation of sulfonated aromatics, p. 169-182. In G. R. Chaudhry (ed.), Biological degradation and bioremediation of toxic chemicals. Chapman \& Hall, London, United Kingdom.

10. Ish-Horowicz, D., and J. F. Burke. 1981. Rapid and efficient cosmid cloning. Nucleic Acids Res. 9:2989.

11. Jahnke, M., T. El-Banna, R. Klintworth, and G. Auling. 1990. Mineralization of orthanilic acid is a plasmid-associated trait in Alcaligenes sp. O-1. J. Gen. Microbiol. 136:2241-2249.

12. Jahnke, M., F. Lehmann, A. Schoebel, and G. Auling. 1993. Transposition of the TOL catabolic genes (Tn4651) into the degradative plasmid pSAH of Alcaligenes sp. O-1 ensures simultaneous mineralization of sulpho- and methyl-substituted aromatics. J. Gen. Microbiol. 139:1959-1966.

13. Junker, F., R. Kiewitz, and A. M. Cook. 1997. Characterization of the toluenesulfonate operon tsaMBCD and tsaR in Comamonas testosteroni T-2. J. Bacteriol. 179:919-927.

14. Junker, F., E. Saller, H. R. Schläfli Oppenberg, P. M. H. Kroneck, T. Leisinger, and A. M. Cook. 1996. Degradative pathways for $p$-toluenecarboxylate and $p$-toluenesulfonate and their multi-component oxygenases in Comamonas testosteroni strains PSB-4 and T-2. Microbiology (Reading) 142: 2419-2427.

15. Lange, F. T., M. Wenz, and H.-J. Brauch. 1995. Trace-level determination of aromatic sulfonates in water by on-line ion-pair extraction/ion-pair chromatography and their behaviour in the aquatic environment. J. High Resol. Chromatogr. 18:243-252.

16. Locher, H. H., T. Leisinger, and A. M. Cook. 1991. 4-Toluene sulfonate methyl-monooxygenase from Comamonas testosteroni T-2: purification and some properties of the oxygenase component. J. Bacteriol. 173:3741-3748.

17. Locher, H. H., C. Malli, S. Hooper, T. Vorherr, T. Leisinger, and A. M. Cook. 1991. Degradation of $p$-toluic acid ( $p$-toluene carboxylic acid) and $p$-toluene sulphonic acid via oxygenation of the methyl sidechain is initiated by the same set of enzymes in Comamonas testosteroni T-2. J. Gen. Microbiol. 137:2201-2208.

18. Locher, H. H., B. Poolman, A. M. Cook, and W. N. Konings. 1993. Uptake of 4-toluenesulfonate by Comamonas testosteroni T-2. J. Bacteriol. 175:10751080 .

19. Mason, J. R., and R. Cammack. 1992. The electron-transport proteins of hydroxylating bacterial dioxygenases. Annu. Rev. Microbiol. 46:277-305.

20. Nakatsu, C., J. Ng, R. Singh, N. Straus, and R. C. Wyndham. 1991. Chlorobenzoate catabolic transposon Tn5271 is a composite class I element with flanking class II insertion sequences. Proc. Natl. Acad. Sci. USA 88:83128316.

21. Nakatsu, C. H., N. A. Straus, and R. C. Wyndham. 1995. The nucleotide sequence of the Tn5271 3-chlorobenzoate 3,4-dioxygenase genes (cbaAB) unites the class IA oxygenases in a single lineage. Microbiology (Reading) 141:485-495.

22. Neilson, J. W., K. L. Josephson, I. L. Pepper, R. B. Arnold, G. D. Di Giovanni, and N. A. Sinclair. 1994. Frequency of horizontal gene transfer of a large catabolic plasmid (pJP4) in soil. Appl. Environ. Microbiol. 60:40534058.

23. Pansegrau, W., E. Lanka, P. T. Barth, D. H. Figurski, D. G. Guiney, D. Haas, D. R. Helinski, H. Schwab, V. A. Stanisich, and C. M. Thomas. 1994. Complete nucleotide sequence of Birmingham IncP $\alpha$ plasmids. J. Mol. Biol. 239:623-663.

24. Pettigrew, C. A., A. Breen, C. Corcoran, and G. S. Sayler. 1990. Chlorinated biphenyl mineralization by individual populations and consortia of freshwater bacteria. Appl. Environ. Microbiol. 56:2036-2045.

25. Ramos-Gonzalez, M. I., E. Duque, and J. L. Ramos. 1991. Conjugational transfer of recombinant DNA in cultures and in soils: host range of Pseudomonas putida TOL plasmids. Appl. Environ. Microbiol. 57:3020-3027.

26. Sanger, F., S. Nicklen, and A. R. Coulson. 1977. DNA sequencing with chain-terminating inhibitors. Proc. Natl. Acad. Sci. USA 74:5463-5467.

27. Sayler, G. S., S. W. Hooper, A. C. Layton, and J. M. H. King. 1990. Catabolic plasmids of environmental and ecological significance. Microb. Ecol. 19:120.

28. Schläfli, H. R., M. A. Weiss, T. Leisinger, and A. M. Cook. 1994. Terephthalate 1,2-dioxygenase system from Comamonas testosteroni T-2: purification and some properties of the oxygenase component. J. Bacteriol. 176: 6644-6652.

29. Schläfli Oppenberg, H. R., G. Chen, T. Leisinger, and A. M. Cook. 1995. Regulation of the degradative pathways from 4-toluenesulphonate and 4-toluenecarboxylate to protocatechuate in Comamonas testosteroni T-2. Microbiology (Reading) 141:1891-1899.

30. Schuurman, R., and W. Keulen. 1991. Modified protocol for DNA sequence analysis using sequenase 2.0. BioTechniques 10:185.

31. Smith, C. A., and C. M. Thomas. 1987. Comparison of the organisation of the genomes of phenotypically diverse plasmids of incompatibility group $\mathrm{P}$ : members of the IncP $\beta$ sub-group are closely related. Mol. Gen. Genet. 206:419-427.

32. Smith, C. L., S. R. Klco, and C. R. Cantor. 1988. Pulsed-field gel electrophoresis and the technology of large DNA molecules. In K. E. Davies (ed.), Genome analysis: a practical approach. IRL Press, Oxford, United Kingdom.

33. Springael, D., S. Kreps, and M. Mergeay. 1993. Identification of a catabolic transposon, Tn4371, carrying biphenyl and 4-chlorobiphenyl degradation genes in Alcaligenes eutrophus A5. J. Bacteriol. 175:1674-1681.

34. Tabor, C. F., and L. B. Barber II. 1996. Fate of linear alkybenzene sulfonate in the Mississippi river. Environ. Sci. Technol. 30:161-171.

35. Tardif, G., C. W. Greer, D. Labbe, and P. C. Lau. 1991. Involvement of a large plasmid in the degradation of 1,2-dichlorethene by Xanthobacter autotrophicus. Appl. Environ. Microbiol. 57:1853-1857.

36. Thurnheer, T., T. Köhler, A. M. Cook, and T. Leisinger. 1986. Orthanilic acid and analogues as carbon sources for bacteria: growth physiology and enzymatic desulfonation. J. Gen. Microbiol. 132:1215-1220.

37. Top, E. M., W. E. Holben, and L. J. Forney. 1995. Characterization of diverse 2,4-dichlorophenoxyacetic acid-degradative plasmids isolated from soil by complementation. Appl. Environ. Microbiol. 61:1691-1698.

38. van der Meer, J. R., W. M. de Vos, S. Harayama, and A. J. B. Zehnder. 1992 Molecular mechanisms of genetic adaptation to xenobiotic compounds. Microbiol. Rev. 56:677-694.

39. van Loon, W. M. G. M., J. J. Boon, and B. de Groot. 1993. Quantitative analysis of sulfonic acid groups in macromolecular lignosulfonic acids and aquatic humic substances by temperature-resolved pyrolysis-mass spectrometry. Environ. Sci. Technol. 27:2387-2396.

40. Villarroel, R., R. W. Hedges, R. Maenhaut, J. Leemans, G. Engler, M. Van Montagu, and J. Schell. 1983. Heteroduplex analysis of P-plasmid evolution: the role of insertion and deletion of transposable elements. Mol. Gen. Genet. 189:390-399.

41. Wang, Y. Z., Y. Zhou, and G. J. Zylstra. 1995. Molecular analysis of isophthalate and terephthalate degradation by Comamonas testosteroni YZW-D Environ. Health Perspect. 130:9-12.

42. Willems, A., B. Pot, E. Falsen, P. Vandamme, M. Gillis, K. Kersters, and J. de Ley. 1991. Polyphasic taxonomic study of the emended genus Comamonas: relationship to Aquaspirillum aquaticum, E. Falsen group 10, and other clinical isolates. Int. J. Syst. Bacteriol. 41:427-444.

43. Wyndham, R. C., A. E. Cashore, C. H. Nakatsu, and M. C. Peel. 1994 Catabolic transposons. Biodegradation 5:323-342.

43a.Wyndham, R. C. Personal communication.

44. Yakobson, E., and D. Guiney. 1983. Homology in the transfer origins of broad host range IncP plasmids: definition of two subgroups of $\mathrm{P}$ plasmids. Mol. Gen. Genet. 192:436-438. 